NBER WORKING PAPER SERIES

DOES THE FEDERAL RESERVE CARE ABOUT THE REST OF THE WORLD?

\author{
Barry Eichengreen \\ Working Paper 19405 \\ http://www.nber.org/papers/w19405 \\ NATIONAL BUREAU OF ECONOMIC RESEARCH \\ 1050 Massachusetts Avenue \\ Cambridge, MA 02138 \\ September 2013
}

Prepared for the NBER Symposium on the First 100 Years of the Federal Reserve, July 10, 2013. I thank Christina, David Romer, and the editors of this journal for comments and Chris Krogslund for research assistance. The views expressed herein are those of the author and do not necessarily reflect the views of the National Bureau of Economic Research.

NBER working papers are circulated for discussion and comment purposes. They have not been peerreviewed or been subject to the review by the NBER Board of Directors that accompanies official NBER publications.

(C) 2013 by Barry Eichengreen. All rights reserved. Short sections of text, not to exceed two paragraphs, may be quoted without explicit permission provided that full credit, including $\odot$ notice, is given to the source. 
Does the Federal Reserve Care About the Rest of the World?

Barry Eichengreen

NBER Working Paper No. 19405

September 2013

JEL No. E4,N1

\begin{abstract}
$\underline{\text { ABSTRACT }}$
Many economists are accustomed to thinking about Federal Reserve policy in terms of the institution's dual mandate, which refers to price stability and high employment, and in which the exchange rate and other international variables matter only insofar as they influence inflation and the output gap - which is to say, not very much. This conventional view is heavily shaped by the distinctive circumstances of the last three decades, when the influence of international considerations on Fed policy has been limited. I discuss how the Federal Reserve paid significant attention to international considerations in its first two decades, followed by relative inattention to such factors in the two-plus decades that followed, then back to renewed attention to international aspects of monetary policy in the 1960s, before the recent period of benign neglect of the international dimension. This longer perspective is a reminder that just because the Fed has not attached priority to international aspects of monetary policy in the recent past is no guarantee that it will not do so in the future.
\end{abstract}

Barry Eichengreen

Department of Economics

University of California, Berkeley

549 Evans Hall 3880

Berkeley, CA 94720-3880

and NBER

eichengr@econ.Berkeley.edu 


\section{Does the Federal Reserve Care About the Rest of the World? ${ }^{1}$}

\section{Barry Eichengreen}

Many economists are accustomed to thinking about Federal Reserve policy in terms of the institution's "dual mandate," which refers to price stability and high employment, and in which the exchange rate and other international variables matter only insofar as they influence inflation and the output gap - which is to say, not very much.

In fact, this conventional view is heavily shaped by the distinctive and peculiar circumstances of the last three decades, when the influence of international considerations on Fed policy has been limited. In this paper, I will discuss how the Federal Reserve paid significant attention to international considerations in its first two decades, followed by relative inattention to such factors in the two-plus decades that followed, then back to renewed attention to international aspects of monetary policy in the 1960s, before the recent period of benign neglect of the international dimension. This longer perspective is a reminder that just because the Fed has not attached priority to international aspects of monetary policy in the recent past is no guarantee that it will not do so in the future. Indeed, I will argue in the conclusion that in the next few decades, international aspects are likely to play a larger role in Federal Reserve policymaking. ${ }^{2}$

\section{International from the Start}

The founding of the Federal Reserve in 1913 is commonly portrayed in terms of domestic financial-stability considerations. Prior to 1914 financial crises were frequent. Interest rates spiked in the planting and harvest seasons, giving rise to financial stringency and instability. There was dissatisfaction with how market participants had managed the most recent crisis in 1907. The Fed was therefore created "to furnish an elastic currency... and for other purposes" in the words of the Federal Reserve Act of 1913. Importantly, the Act did nothing to change the international dimension of American monetary policy. The dollar was still convertible exclusively into gold at \$20.67 a troy ounce, as it had been since the Gold Standard Act of 1900. Federal Reserve Banks were now obliged hold gold in the amount of 40 per cent of their notes (and gold and other eligible assets equal to 35 per cent of deposits and reserves) and to pay out gold at this price.

But this is only part of the story. Political agreement to create a new central banking institution required building a coalition. In addition to those desiring a more elastic currency, there were exporters, importers and financiers interested in establishing a market in dollar-

\footnotetext{
${ }^{1}$ Prepared for the NBER Symposium on the First 100 Years of the Federal Reserve, July 10, 2013. I thank Christina, David Romer, and the editors of The Journal of Economic Perspectives for comments and Chris Krogslund for research assistance.

${ }^{2}$ The treatment here is necessarily summary in form. For readers interested in additional rigor and detail on the intersection of international issues and monetary policy, some starting points would be Gali and Gertler (2010), which is an especially useful compendium of recent scholarship; Friedman and Schwartz's (1963) Monetary History of the United States, which touches more than incidentally on the role of international factors in Fed decision making; and my personal favorite, William Adams Brown's (1940) The International Gold Standard Reinterpreted, which devotes successive chapters to the United States and its central bank.
} 
denominated trade credits and enhancing the currency's role as a vehicle for international investment (Broz 1997). Attaining these goals required creating a central bank to provide liquidity to international markets. Before World War I, the US dollar and American financial firms played little role in financing international trade, including even the trade of U.S. importers and exporters. A U.S. coffee roaster seeking to import beans from Brazil would request a letter of credit from its bank, and that bank in turn would arrange a letter of credit denominated in pounds sterling with its London correspondent, because that was the only instrument that the Brazilian exporter would accept. Taking payment in dollars was unattractive, given the volatility of US markets. In addition, because US banks were prohibited from branching abroad, exporters to US markets faced practical difficulties in converting US dollar payments back into their local currencies.

Thus, the New York financial community found itself unable to compete with London for an important source of business. US importers and exporters faced a competitive disadvantage from having to pay two commissions, one to their local bank and one to its London correspondent, in order to arrange trade credit. Paul Warburg, the German-born financier who was heavily involved in drawing up the blueprint that became the Federal Reserve Act, was familiar from his career in the import-export and banking business in Hamburg and London with the advantages that European economies derived from possessing local markets "trade acceptances"--the contemporary name for what we now call trade credits. These are essentially explicit documented promises by the purchaser of a good produced in another country to pay for a purchase at a future time.

Agreement to establish the Fed required building an alliance between those with financial-stability concerns and these other groups seeking the remedy the problems created by the absence of a trade-acceptance market. The Federal Reserve Act thus authorized U.S. banks to branch abroad to originate foreign business. And one of the first initiatives of the new central bank was to take steps to foster a market in acceptances (LaRoche 1993; Eichengreen and Flandreau 2012). A key challenge in creating a new financial market is the problem of developing liquidity. Without a minimum level of transactions, the market will lack liquidity; conversely, if the market lacks liquidity no one will transact. This was the chicken-and-egg problem that the Fed, seeking to foster a market in acceptances, faced in the 1920s. It responded by stepping in as buyer and liquidity provider of last resort, purchasing US dollar trade acceptances when private demand was lacking. For much of the 1920s, the Fed it was the dominant purchaser. Its efforts succeeded in that New York and the dollar matched and in some years surpassed London and sterling as a source of credit for global trade. This was a startling change from before 1914.

In addition to underscoring the early Fed's international orientation, this episode had two further features relevant to modern central banking. First, a policy of direct Federal Reserve purchases in credit markets with liquidity problems - while a controversial aspect of recent policy -- is not at all unprecedented. Second, the success of the 1920s was fleeting. When international trade declined in the 1930s, the market in trade acceptances declined even more rapidly. The other investors who the Fed had sought to attract by providing liquidity and stabilizing pricing never entered the market in large numbers. It is tempting to speculate that the Fed's overwhelming buy-side dominance crowded out potential entrants. When the central bank curtailed its involvement in the trade acceptance market the 1930s, at a time when it had bigger fish to fry, the market collapsed. 
The Federal Reserve Bank of New York was the single most active participant in the US dollar acceptance market, which is no surprise given that the bulk of acceptance business was transacted in New York. The New York Fed similarly took the lead on the new central bank's other international policy initiative, namely, reconstruction and maintenance of the international gold standard. Its leadership reflected the views of Benjamin Strong, the influential governor of the Federal Reserve Bank of New York. Strong saw exchange rate stability - an important corollary of the gold standard - as critical for the expansion of international trade, and international trade as key to U.S. prosperity. Great Britain had traditionally been at the center of the gold standard system; only if it now restored gold convertibility were other countries apt to follow.

Thus, in the spring and summer of 1924, the New York bank cut its discount rate (the interest rate it charged when advancing money to exporters and their banks by purchasing trade acceptances) by a cumulative 150 basis points, as shown in Figure 1, with the objective of making the pound sterling a relatively more attractive investment, inducing capital to flow from New York to London, and helping the Bank of England push sterling up to the prewar exchange rate against the dollar, where it could then be stabilized (Clarke 1967). ${ }^{3}$ To ensure a wider impact on financial markets, the New York Fed also purchased US Treasury securities, in the course of so doing helping to establish the efficacy of open market operations as an instrument of monetary control. After importing gold for 51 consecutive months from December 1920 to April 1925, the United States now exported it instead. In January 1925 the Federal Reserve agreed to advance the British Treasury an additional \$200 million in gold while encouraging a banking syndicate led by J.P. Morgan to provide a $\$ 100$ million line of credit.

This was not an act of altruism: Strong firmly believed that helping Britain back onto the gold standard, by paving the way for a broader stabilization of exchange rates, would lend stimulus to U.S. exports and economic growth. But that view was not universally shared within the Federal Reserve System. Strong's initiative was criticized, for example, by Adolph Miller, founding governor of the Federal Reserve System and previously professor at the University of California, Berkeley. Miller argued that the resulting monetary policy was inappropriately loose for domestic circumstances. Along with others like then-Secretary of Commerce Herbert Hoover, Miller warned that low interest rates were fueling unsustainable real estate bubbles across Florida and from Detroit to Chicago. This was the first full-blown controversy within the Federal Reserve over the relative importance of domestic and international objectives.

The second controversy arose in 1927, when Strong again proposed cutting interest rates, this time in order to help Britain stay on the gold standard. Miller would have objected, but he was on summer holiday in California. When he returned he mounted a strenuous attack on the policy as inappropriate for an economy already recovering from a brief recession. Monetary historians have been similarly critical (as described in Meltzer 2002), suggesting that a policy looser than appropriate from a domestic standpoint helped to fuel the commercial real estate boom and Wall Street run-up of the late 1920s, both of which came down with a crash. Better, they conclude, would have been for the Fed to keep its eye on the domestic ball.

\footnotetext{
${ }^{3}$ At this time, individual Federal Reserve Banks were free to change their own discount rates, subject to the review and determination of the Federal Reserve Board.
} 
The traditional constraint in which a central bank needs to hold interest rates high to attract capital inflows and defend the exchange rate then reemerged, with a vengeance, late in 1931. In a shock to financial markets, Britain departed from the gold standard on September 21, 1931. The dollar weakened against the continental European currencies, and gold losses mounted rapidly. In part this reflected worries about U.S. competitiveness as it became clear that some two dozen other countries were preparing to follow Britain in devaluing their currencies. Even more important was psychological contagion - the wake-up-call effect - since if one reservecurrency country could depreciate its currency, it was no longer inconceivable that the other, the United States, might follow.

At this point the Fed made its priorities unambiguously clear. On October 8, 1931, the directors of the New York Fed voted to raise its discount rate by 100 basis points and then a week later by another 100 basis points. Other Reserve Banks followed. These higher interest rates were designed to attract financial capital from abroad, or at least discourage it from leaving, thereby supporting the dollar. The wisdom of the decision can be questioned, coming as it did in the midst of the Great Depression be questioned, when domestic conditions warranted lower interest rates. But it clearly privileged exchange rate stability over price stability, financial stability and economic stability.

The final attack on the dollar came in February-March 1933 in the interregnum between the Hoover and Roosevelt administrations. Worries that the new president might devalue something that only he, together with the Congress, and not the Federal Reserve could decide encouraged capital flight from the US to France, Switzerland and Belgium, countries seen as having stronger currencies (Wigmore 1987). The decision in February 1933 to let Henry Ford's Union Guardian Trust Company go under - the equivalent for its time of the September 2008 bankruptcy of Lehman Brothers - then ignited a nationwide banking panic (Kennedy 1973; Awalt 1969). At this point there was essentially no choice but to embargo gold exports, close the banks, and regroup. On his first day in office, President Franklin Roosevelt invoked the Trading with the Enemy Act for the necessary authority. ${ }^{4}$

At this point, the first era in which international considerations played a prominent role in U.S. monetary policy drew to a close. President Roosevelt took the next step in April 1933, making clear that there would be no early return to the gold standard. Currency would no longer be exchanged for gold, and individuals were required to turn in their gold and to receive currency in exchange. The Congress then passed a joint resolution canceling all contracts, public and private, that called for payment in gold. Starting in October, FDR used the authority of the Reconstruction Finance Corporation, an emergency agency created in 1932, to purchase gold with dollars. Pushing up the dollar price of gold was equivalent to pushing down the exchange rate of the dollar against the currencies of other countries still on the gold standard. In effect the Executive Branch had taken emergency control of monetary policy. Finally in January 1934 the president agreed to stabilize the price of gold at $\$ 35$ an ounce. This was not a formal return to the gold standard, since freedom for individuals to hold gold and the reintroduction of gold clauses into private and government contracts were not part of the bargain. Nonetheless, changes in the gold stock again translated into changes in the monetary base (the money supply narrowly

\footnotetext{
${ }^{4}$ One can't help but be reminded of UK Chancellor of the Exchequer Gordon Brown invoking the UK AntiTerrorism Act to prevent the repatriation of Icelandic assets in 2008.
} 
defined) - with some important exceptions detailed below - since the government again bought gold for currency when it flowed in from abroad to keep the dollars price from falling.

These steps inaugurated a new era in which international considerations played little role in U.S. monetary policy. There was no need for high interest rates to stem capital outflows. The new higher dollar price of gold attracted the yellow metal toward the U.S.; more generally, devaluation enhanced the country's international competitiveness. In addition, as the outlines of World War II became visible, foreign capital fled in growing volumes to American shores. Foreign economic and financial conditions mattered less for the U.S. economy than in the 1920s, now that global trade had collapsed due to the imposition of higher tariffs, and long-term international investment had been discouraged by exchange controls and sovereign debt defaults.

\section{On the Horns of the Triffin Dilemma}

After FDR stabilized the price of gold at \$35 an ounce, the Federal Reserve and the U.S. Treasury jousted over who would control monetary policy. Standard practice was for Treasury to purchase all gold inflows using funds in its account at the Federal Reserve, print "gold certificates" in the same dollar amount, and deposit those certificates with the Fed, where they could back an increase in the supply of money and credit. But on some occasions, notably in 1937, when it grew worried about inflation, Treasury would place its gold certificates in an "inactive" account where they could not be used to expand the money supply. This practice was known as "gold sterilization." The Fed might still seek to influence the money supply by changing the discount rate or reserve requirements for the banks. But Treasury's sterilization policy could frustrate or, as in 1937, undesirably amplify the effects (Irwin 2012).

Confronted with a US Treasury that was seeking to carry out monetary policy in this way, the Fed sought to regain the ability to influence money and credit market. Its campaign was unsuccessful: with the outbreak of World War II and the very large government deficits of that time, the Fed was drafted into keeping federal borrowing costs low by holding interest rates on Treasury bills at 0.375 percent and Treasury bonds at 2.5 percent. The practice continued, despite growing Fed resistance, for two years following World War II. Current controversies over how a change in Federal Reserve policy would affect federal government borrowing costs in some ways echo this earlier situation.

This long period of fiscal dominance over monetary policy eventually came to an end with the Treasury-Fed Accord of 1951, which officially ended the expectation that the Fed would purchase US Treasury securities in whatever quantities were necessary to keep interest rates at these low levels. Recent scholarship portrays monetary policy over the balance of the 1950s in a relatively favorable light (for example, Romer and Romer 2002a). More pertinent from the standpoint of this paper, monetary policy at this time focused on keeping inflation low and, to a lesser extent, on responding to temporary deviations from full employment. The Minutes of the Federal Open Market Committee in this period (available online at http://fraser.stlouisfed.org/publication/?pid=677) offer little emphasis or even mention of the US dollar exchange rate, the US balance of payments, or the effect of US monetary policy on the rest of the world. Of course, the discussions do mention of exports and imports, since these variables were seen by members of the committee as containing information useful for forecasting the future paths of inflation and what would later be called the "output gap." 
But beyond that, international factors do not appear to have impinged on the committee's deliberations. There was a commitment after the Bretton Woods agreement of 1944 to continue stabilizing the price of gold at $\$ 35$ an ounce and pay out gold on demand to official foreign creditors, but no matter. This was the period of the "dollar shortage." The term refers to the difficulty experienced by other countries in acquiring, whether through exporting or foreign borrowing, the dollars they needed in order to finance merchandise imports from the United States (Kindleberger 1950). At this time, gold held by the U.S. monetary authorities far exceeded the foreign liabilities of the Federal Reserve, U.S. commercial banks and the U.S. government combined. In this sense, the orientation of monetary policy was not constrained by international implications.

This situation began to change around 1960, when U.S. foreign monetary liabilities first threatened to exceed U.S. gold reserves. Investors worried that John F. Kennedy, if elected president, might follow in Roosevelt's footsteps and devalue the dollar to get the economy "moving again" (to quote Kennedy's campaign literature). Robert Triffin (1960) published the first of a series of books in which he warned that if the dollar remained the only source of global liquidity (other than gold, which still lurked behind the scenes at the agreed-upon price of $\$ 35$ per ounce), a crisis of confidence in the greenback would ultimately develop. Triffin's dilemma was based on the insight that the expansion of the global economy would bring growing demands for international liquidity. If dollar-denominated claims, and specifically U.S. Treasury bonds, were the primary source of such liquidity (on the margin), then U.S. foreign liabilities would eventually come to exceed U.S. gold reserves. When this occurred, it would call into question the ability of the U.S. authorities to convert these liabilities into gold at the fixed price of $\$ 35$ an ounce, creating crisis of confidence. Alternatively, if the authorities took steps to limit US current account deficits and foreign lending, the rest of the world would be starved of liquidity in an ongoing "dollar shortage," and international transactions generally would suffer.

The expectation that President Kennedy would devalue the US dollar proved erroneous, but the other worries were not without foundation. Inflation accelerated in the later 1960s and grew more erratic. The goals of Federal Reserve policy shifted from an overarching emphasis on inflation to greater attention to unemployment and economic growth. Romer and Romer (2002b) argue that this period saw a revolution in ideas in which policymakers forgot much of what they had learned about the natural rate of unemployment. Instead, they overestimated potential output and succumbed to the temptation to use monetary policy to target real variables. Fed chairman William McChesney Martin believed that the Fed had an obligation to help keep federal debt service at manageable levels, which constrained monetary policy as budget deficits grew.

Even if the Fed was concerned about its gold losses and other international variables, it might nonetheless be hard to detect that concern amongst these other changes. However, Bordo and Eichengreen (2008) argue that the Fed paid considerable attention to balance-of-payments considerations in the first half of the 1960s, tightening when it grew worried by the pace of gold outflows. In addition to his concern with debt service, Fed Chairman Martin was a firm believer in maintenance of the gold peg. Already in 1960, the Fed abandoned its traditional "bills-only policy" (the policy of buying only short-term Treasury debt) in order to let short-term interest rates rise, attract capital flows and strengthen the balance of payments (Solomon 1977, p. 36). The Minutes of the FOMC regularly refer to balance-of-payments considerations. Many of these statements, in an echo of the 1920s, came from President of the Federal Reserve Bank of New 
York, now Alfred Hayes (Meltzer 2008). A count of references in the minutes and memoranda of the FOMC, as available from 1950 through March 1976, normalized by pages, shows mention (and presumably concern) with the balance of payments mounting in the first half of the 1960s and peaking around mid-decade, as shown in Figure 2. ${ }^{5}$

Of course, mentioning international issues in the minutes is not the same as taking action with these issues in mind, so Bordo and Eichengreen (2008) attempt to identify the role of those mentions (and that concern) in the policy decisions of the Federal Open Market Committee. They identify seven occasions when policy action was motivated primarily by international considerations, and 23 when it was motivated by a combination of domestic and international factors. That is, only rarely were international factors an overriding consideration, but they generally combined with domestic factors to prompt policy action. The total of 30 such instances suggests that international considerations were not inconsequential. The majority of these instances were in the period through 1965 (although international considerations were also invoked during crisis episodes in 1967-8 and 1971). These international concerns help to explain why monetary policy in the first half of the 1960s was tighter than would be expected on the basis of inflation and the output gap alone (Bordo and Eichengreen 2008; Taylor 1999). ${ }^{6}$

What changed between the first and second halves of the 1960s that made international considerations less salient for Federal Reserve policy-makers? In the first half of the decade, balance-of-payments management had effectively been a shared a shared responsibility of the Treasury and the Fed. But as the Treasury pushed for adoption of an "interest equalization tax" - a tax on purchases of foreign securities by US investors - and took a variety of other policy measures designed to strengthen the balance of payments, it assumed primary responsibility for balance-of-payments management. In addition, measures like the interest equalization tax had effects tantamount to capital-flow taxes and controls. They gave the central bank some room looser monetary with less concern that it would encourage an outflow of investment capital. Whether these steps were good policy is debatable (Meltzer 1991 offers a critical assessment). The acceleration of inflation and mounting political pressure on Chairman Arthur Burns for loose monetary policy starting in 1970 suggests that there would have been benefits to the Federal Reserve if it had continued to perceive itself as under the external constraint under which it operated in the first half of the 1960 s

\section{After Bretton Woods}

\footnotetext{
${ }^{5}$ Where dots are missing in Figure 2(as in the first half of the 1950s), there were zero mentions. Normalizing by pages adjusts for the fact that the minutes and memoranda tended to grow longer over time, although raw counts show basically the same picture. In principle, it should be possible to extend this analysis beyond 1976 when transcripts of FOMC meetings become available. However, the transcripts are sharply discontinuous with the minutes in terms of comprehensiveness; in addition, pagination and font size are quite different, and the pagination and format of the transcripts themselves are not constant over time. This makes trends in both raw and per-page counts more difficult to interpret. I have resisted the temptation. The outlier in mid-1963 is from a meeting in a period of heightened concern about dollar stability (Eichengreen 2000). The Federal Reserve System had recently drawn its full \$150 million swap line with the Bundesbank, and dollar weakness had been a prominent topic at the most recent monthly meeting of the Bank for International Settlements, where the Fed had been represented by Charles Coombs of the Federal Reserve Bank of New York.

${ }^{6}$ Romer and Romer (2002b, p.57) similarly make the point that balance-of-payments considerations prevented the Fed from being as expansionary as it would have otherwise wanted in the first half of the 1960s.
} 
The 1970s was a decade of mixed signals and uncertainty about Federal Reserve policy. Unconstrained by the exchange rate, or for that matter much else, monetary policy drifted. This changed in 1977 when Congress amended the Federal Reserve Act to include the "dual mandate" that monetary policy should consider both stable prices and maximum employment, and in 1979 when Paul Volcker succeeded G. William Miller as chairman of the Federal Reserve and made inflation control a priority. The touchstones of policy became deviations of inflation from low single digits and fluctuations in the output gap. ${ }^{7}$ One finds periodic mention of international considerations in the minutes and transcripts of the Federal Open Market Committee of this time, but it is clear that these variables mattered principally insofar as they were relevant to the future evolution of inflation and the output gap.

A combination of factors explains why international factors were less influential in the late 1970s and early 1980s than in the 1920s, 1930s and 1960s. After the final collapse of the Bretton Woods agreement in 1973, there was no longer an exchange rate peg or statutory gold price to defend. The 1977 legislation gave the Fed a mandate to pursue price stability and full employment but said nothing about the exchange rate, balance-of-payments or international financial stability. The experience of the 1970s had taught that a Federal Reserve that failed to achieve price stability would lack the credibility to successfully pursue other economic and financial goals. The U.S. economy was large and closed enough that the Fed could afford to act to a first approximation like the central bank of a closed economy. The U.S. share of world GDP peaked in 1985 at 33 percent, at a time when the Soviet economy was in decline and China's growth spurt had just begun. ${ }^{8}$ The U.S. trade/GDP ratio was rising but more slowly than in the subsequent quarter century. The explosive growth of international capital flows and deepening of international financial linkages was yet to come.

International considerations did in some circumstances play a role in monetary policy during this time. Volcker's inflation-control strategy itself had an international dimension; the fact that higher interest rates meant a stronger dollar made for sharper disinflation through the channel of lower import prices (as argued by Sachs 1985). ${ }^{9}$ The Fed's decision to back away from a very tight monetary policy in 1982 may have been influenced by the outbreak of the Latin American debt crisis and the threat this posed to the solvency of major U.S. banks (which is not to deny that there was also an influence of the recession in 1981-2). Central bank governors as well as finance ministers were party to the Plaza Agreement of 1985 between the US, the UK, France, Germany and Japan to attempt to stem the continued rise of the dollar exchange rate. This led to coordinated foreign exchange market intervention and, in March 1986, coordinated interest rate reductions. Starting in 1986, central bank governors of the so-called G-7 countries (the United States, United Kingdom, France, Germany, Italy, Canada and Japan) met regularly, together with their finance-ministry counterparts, on the sidelines of the spring and fall meetings of the IMF and World Bank. In addition, senior central bank officials met bi-monthly at the

\footnotetext{
${ }^{7}$ Indeed, the observation of how the federal funds interest rate changed with differences in inflation and unemployment after 1983 is what led the eponymous Professor Taylor to develop his rule.

${ }^{8}$ One should be cautious about these comparisons, because they depend on the exchange rate used to value transactions in dollars, and, 1985 was when the dollar exchange rate was at a local peak. At purchasing power parity, the US share of the global economy was more like 23 percent in 1985, and reaches another local peak in 1999. Economists will of course debate which valuation method is more relevant when considering the conduct of monetary policy.

${ }^{9}$ Nelson (2005) argues that the FOMC had something similar in mind when it tightened in 1978.
} 
Bank of International Settlements. These meetings facilitated information exchange. They also facilitated coordinated foreign-exchange-market intervention, frequently before the mid-1990s and sporadically thereafter: in June 1998 when the yen depreciated in the wake of the Asian crisis, in September 2000 when the euro weakened reflecting uncertainty about the policies of Europe's new central bank, and in March 2011 in response to the rise of the yen induced by the Fukushima Earthquake and the liquidation of foreign assets by Japanese insurance companies. ${ }^{10}$

The global economic and financial crisis that unfurled in 2007 is another reminder that the Fed cannot afford to neglect the impact of its policies on conditions abroad or the implications of conditions abroad for its policies. On October 8, 2008, in the wake of Lehman Bros. failure, the Federal Reserve coordinated a reduction in the federal funds rate with the lending rates of the European Central Bank, Bank of England, Bank of Canada, Swiss National Bank and Swedish Riksbank. Irwin (2013), with a little exaggeration, calls this the "first globally coordinated easing in history." Unusually, the Fed issued a joint statement together with these other central banks announcing the action, which I interpret as an acknowledgment that coordinating policy with foreign central banks might produce better outcomes under the circumstances.

In addition, the Fed arranged dollar swap lines with 14 foreign central banks starting in December 2007 when the subprime crisis intensified. In these arrangements, the Federal Reserve stands ready to swap US dollars with other central banks for the currencies of that bank. The Fed renewed five of those dollar swap lines, notably that with the European Central Bank, in May 2010. These swap facilities were designed to alleviate financial problems abroad and limit the blowback to U.S. markets if foreign banks, unable to secure US dollar funding, were forced to liquidate their holdings of U.S. securities. These swap lines were an acknowledgement that what happens abroad doesn't always stay abroad and, while not modifying monetary policy to take this fact into account, that the Fed must develop ancillary policy instruments to address strains in foreign markets for US dollars. The Board of Governors (2013), in justifying the practice to a skeptical Congress, noted that foreign currency swap lines might also be helpful for addressing financial strains should U.S. institutions experience a shortage of foreign currency-denominated liquidity, although the most recent swaps were not activated for this purpose.

\section{Back to the Future}

The questions are whether international considerations will have a more powerful impact on the U.S. economy in the future and how if at all the Federal Reserve should modify the formulation and conduct of policy to take this into account. I posit three trends that will heighten the impact of international variables on the U.S. economy. First, I assume that the U.S. will continue to grow more open to international trade and financial transactions. Admittedly, this assumption is contestable. While technological progress works inexorably to reduce the costs of international transactions, and - I would argue - also reduces the cost of international relative to domestic transactions, international openness depends not just on technology but also on policy, which has been known to push in the other direction. But bear with me.

\footnotetext{
${ }^{10}$ To be clear, these intervention operations are decided in consultation by the US Treasury and the Federal Reserve. Such operations are typically sterilized with the goal, sometimes questioned by academics, of moving the dollar exchange rate without also moving the monetary base. On the effectiveness of sterilized intervention, a useful starting point is Rogoff (1984).
} 
Second, I assume that emerging and frontier markets will continue to grow more rapidly than mature economies, so that the U.S. economy will come to account for a progressively declining share of the global economy. Again, catch-up and convergence continue are not inevitable; their progress will depend on policy choices. But recent experience makes this assumption a reasonable starting point.

Third, I assume that the US dollar will lose its monopoly as funding currency for international banks and as the all but exclusive vehicle and currency of denomination for international transactions (for discussion, see Shin 2012). This is not to suggest, as does the film Looper, that we will wake up tomorrow and discover that all transactions are conducted in renminbi. ${ }^{11}$ Movement toward other funding and vehicle currencies will be gradual, so that the dollar ends up sharing its international role with other national units. But there is no fundamental reason why the U.S. should be the only country with deep and liquid financial markets open to the rest of the world. Moreover, the United States alone will not be able to provide safe and liquid assets on the scale required by an expanding global economy. It follows that U.S. banks and firms will rely more on foreign currency funding and liquidity in the future than the recent past (Eichengreen 2011).

Taken together, these three trends suggest that shocks to the exchange rate and balance of payments will have a larger impact on the US economy in the future, and that the implications may extend beyond those for inflation and the output gap. For example, US dollar appreciation which creates competitiveness problems for the traded-goods sector will be more of a problem as a larger share of U.S. output and employment is exposed to international competition. If dollar appreciation causes US firms to exit the market and they face fixed costs of reentering (as in Baldwin and Krugman 1989), then transitory currency swings may have permanent welfarereducing effects. This is one explanation for why other open economies adjust their policies in response to movements in the exchange rate. It is an explanation for the aversion to freely floating exchange rates, known as "fear of floating," in emerging markets (Calvo and Reinhart 2002).

A country on the receiving end of large capital inflows, in addition to experiencing a rising exchange rate, is likely to feel unwelcome pressure on housing and financial markets. Capital inflows into the United States in the period leading up to the subprime crisis are an illustration of the problems that can arise. The effect on local markets will be larger the smaller the economy is relative to the rest of the world and the more open it is to global markets. At the time of writing, New Zealand is a case in point of a country that is dealing with these kinds of housing and asset market concerns due to exchange-rate and capital-flow pressures (Wheeler 2013). ${ }^{12}$ More generally, a variety of small open economies, and a number of middle-sized countries like Brazil, have complained about the adverse impact of policies abroad on their

\footnotetext{
${ }^{11}$ Looper, as film buffs know, is set in 2044. In the original script, the protagonist planned to move to Paris "in the future." When the director found filming in Paris prohibitively expensive, the future was shifted to Shanghai, the Chinese distributor having offered to pay for a crew to film there - see http://www.imdb.com/title/tt1276104/trivia ${ }^{12}$ It is tempting to point to Ireland and Spain before 2009 as additional examples, but their cases are special for obvious (euro-related) reasons.
} 
economies, operating through these channels, and have adjusted monetary and other policies to address them. ${ }^{13}$

Finally, as global markets grow relative to the U.S. market, and as international finance is provided in a wider range of currencies, U.S. banks and firms will rely more on foreign currency funding. As they accumulate liabilities denominated in foreign currency, the Federal Reserve may then feel a growing reluctance to let the dollar exchange rate move for fear of the destabilizing balance sheet effects (that banks and firms with foreign-currency-denominated debts will be unable to service them using their domestic-currency earnings). Those adverse balance sheet effects are another explanation for why smaller, more open economies where such currency mismatches are prevalent find it hard to commit to regimes of flexible inflation targeting that imply benign neglect of the exchange rate.

Assume, as a result of the changes posited above, that the effect of the exchange rate and capital flows grows more important. Does it follow that the Fed will have to modify the formulation and conduct of monetary policy to take them into account?

The answer, as with many economic questions, is "yes and no." For example, if a higher level of reliance on foreign currency funding causes exchange rate movements to have more destabilizing balance sheet effects, then the first-best response is not to use monetary policy to prevent those movements, but instead to strengthen prudential supervision and regulation of banks and governance of corporations to prevent excessive exposure to this form of balance sheet risk from arising in the first place. Mishkin and Savastano (2001) is an early statement of the tradeoff between, on the one hand, the strength of supervision and regulation of balance-sheet mismatches, and on the other hand, policies of benign neglect of the exchange rate on the other.

Similarly, if capital inflows place worrisome upward pressure on housing and other asset markets, then the first-best solution is to strengthen lending standards, raise margin requirements, and otherwise address problems in housing and asset markets directly. The second-best set of responses in this case would be to address the capital inflows that are the proximate source of the problem by applying taxes to such inflows and, among other steps, tightening fiscal policy, which should put downward pressure on interest rates and on the exchange rate. Trying to address problems in asset markets caused by inflows of foreign capital by making adjustments in monetary policy would be no more than a third best policy choice.

As yet another example, if the issue is the risk of permanent damage to traded-goods sectors because temporary exchange rate movements have permanent effects, then the first-best response is to eliminate the financial imperfections forcing incumbents to exit and preventing them from reentering, or to use tax and other policies (assuming that these can be enacted in a form compliant with World Trade Organization rules) to address their problems directly.

Readers will detect echoes here of the "lean versus clean debate" (White 2009; Mishkin 2011). The question in that context was whether central banks should lean against asset bubbles. Earlier thinking tended to favor letting other agencies of government - bank supervisors, regulators, those responsible for the conduct of fiscal policy - to address problems of asset

\footnotetext{
${ }^{13}$ For example, Brazilian Finance Minister Guido Mantega, registered strong complaints in a series of press interviews and speeches starting in September 2010.
} 
bubbles using other instruments better suited to the task than monetary policy, and for central banks to limit their intervention to cleaning up the aftereffects. It would be presumptuous to assert that recent events have permanently decided the question in favor of one view or the other. But there is no question that those events have shifted the balance, by suggesting that central banks should think harder about the need to take preemptive action both because other agencies of government may not be doing their part and because cleaning up afterwards can be very costly.

The implication is that precisely the same issues will arise, with growing intensity over time, in connection with movements in exchange rates and capital flows. There will be no return to the gold standard of the 1920s or the Bretton Woods System of the 1950s and 1960s. But as the US economy grows even more open and the rest of the world grows larger, international considerations, operating through these channels, will impinge more directly on the central bank's key objectives of price and economic stability. The Fed will have no choice but to incorporate those considerations more prominently into its policy decisions. 
Figure 1. Discount Rate, Federal Reserve Bank of New York

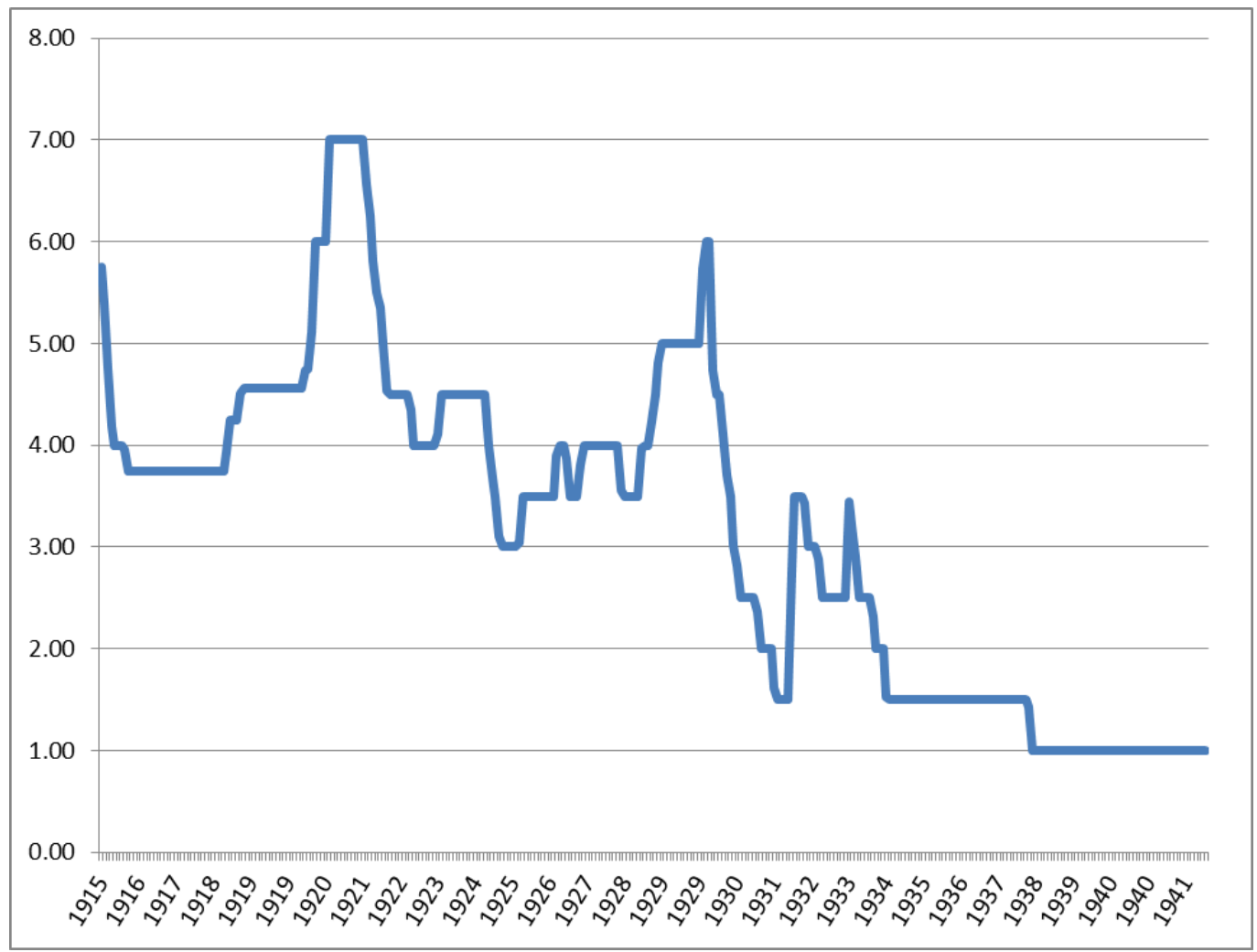

Notes: Data from NBER Macrohistory Data Base (series 13009). 
Figure 2. References to Balance of Payments and Related Terms in the Minutes

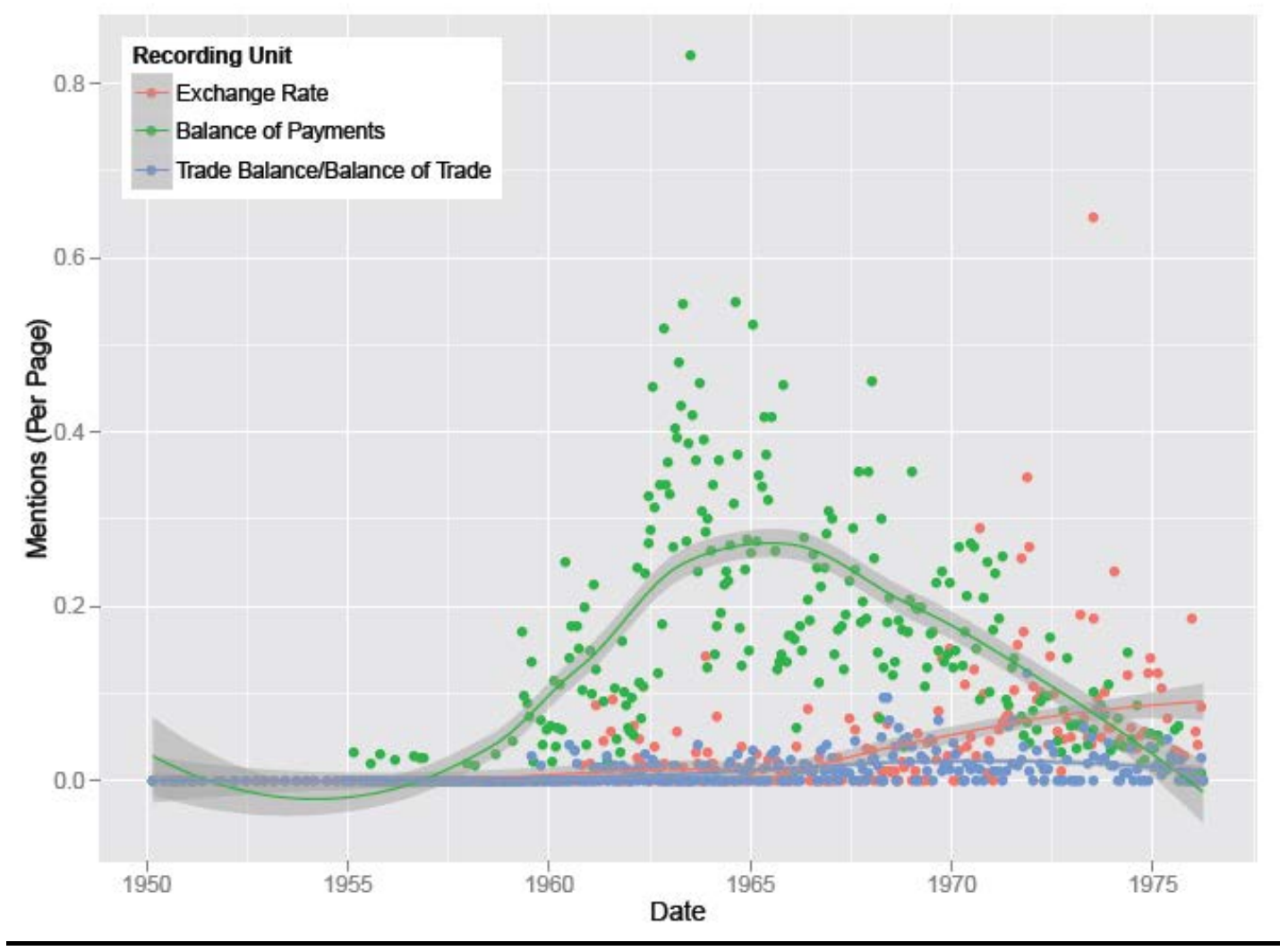

Notes: Mentions for each term are taken from minutes and memoranda of discussion for all meetings and telephone conferences of the Federal Open Market Committee from 1950 through March 1976. Data is fit with a $2^{\text {nd }}$ degree local polynomial LOESS regression with span parameter $\alpha=0.75$ (indicating that 75 of the data are used to estimate each local regression) and a $+/$ - one standard error band. 


\section{References}

Awalt, Francis Gloyd. 1969. "Recollections of the Banking Crisis in 1933." Business History Review 43(3): 347-371.

Baldwin, Richard, and Paul Krugman. 1989. "Persistent Trade Effects of Large Exchange Rate Shocks.” Quarterly Journal of Economics 104(4): 635-654.

Board of Governors of the Federal Reserve System. 2013. "Central Bank Liquidity Swap Lines." Washington, D.C.: Board of Governors of the Federal Reserve System. http://www.federalreserve.gov/newsevents/reform_swaplines.htm.

Bordo, Michael, and Barry Eichengreen. 2008. "Bretton Woods and the Great Inflation." NBER Working Paper14532 (December).

Brown, William Adams. 1940. The International Gold Standard 1914-1934. New York:

National Bureau of Economic Research.

Broz, Lawrence. 1997. International Origins of the Federal Reserve System. Ithaca: Cornell University Press.

Calvo, Guillermo, and Carmen Reinhart. 2002. "Fear of Floating.” Quarterly Journal of Economics 117(2): 379-408.

Clarke, Stephen V.O. 1967. Central Bank Cooperation, 1925-31. New York: Federal Reserve Bank of New York.

Eichengreen, Barry. 2000. "From Benign Neglect to Malignant Preoccupation: U.S. Balance of Payments Policy in the 1960s." In Economic Events, Ideas and Policies: The 1960s and After, edited by George Perry and James Tobin, 185-242.Washington, D.C.: Brookings Institution,

Eichengreen, Barry. 2011. Exorbitant Privilege: The Rise and Fall of the Dollar and the Future of the International Monetary System. New York: Oxford University Press.

Eichengreen, Barry, and Marc Flandreau. 2012. "The Federal Reserve, the Bank of England, and the Rise of the Dollar as an International Currency, 1914-1939." Open Economies Review 23(1): 57-87.

Friedman, Milton, and Anna Schwartz.1963. A Monetary History of the United States, 18671960. Princeton University Press for the National Bureau of Economic Research.

Galí, Jordi, and Mark Gertler, eds. 2010. International Dimensions of Monetary Policy. University of Chicago Press for the National Bureau of Economic Research.

Irwin, Douglas. 2012. “Gold Sterilization and the Recession of 1937-8." Financial History Review 19(3): 249-267.

Irwin, Neil. 2013. The Alchemists: Three Central Banks and a World on Fire. New York: Penguin. 
Kennedy, Susan Eastabrook. 1973. The Banking Crisis of 1933. Lexington: University Press of Kentucky.

Kettl, Donald. 1986. Leadership at the Fed. New Haven: Yale University Press.

Kindleberger, Charles. 1950. The Dollar Shortage. Cambridge: MIT Press.

LaRoche, Robert K. 1993. "Bankers Acceptances." Federal Reserve Bank of Richmond Quarterly Review 79(1): 75-85.

Meltzer, Allan. 1991. "U.S. Policy in the Bretton Woods Era." Federal Reserve Bank of St. Louis Review 73(3): 54-83.

Meltzer, Allan. 2002. A History of the Federal Reserve, Vol. 1, 1913-1951. University of Chicago Press.

Meltzer, Allan. 2008. "Bretton Woods and the Great Inflation: Comment." http://www.nber.org/chapters/c9175.pdf .

Mishkin, Frederic, and Miguel Savastano. 2001. "Monetary Policy Strategies for Latin America." Journal of Development Economics 66(2): 415-444.

Mishkin, Frederic. 2011. "Monetary Policy Strategy: Lessons from the Crisis.” NBER Working Paper 16755 (February).

Nelson, Edward. 2005. "The Great Inflation of the Seventies: What Really Happened?" B.E. Journal of Macroeconomics 5(1): 1-50.

Orphanides, Athanasios. 2003. "The Quest for Prosperity without Inflation.” Journal of Monetary Economics 50(3): 633-663.

Reinhart, Carmen, and Kenneth Rogoff. 2013. "Shifting Mandates: The Federal Reserve's First Centennial.” NBER Working Paper 18888 (March).

Rogoff, Kenneth. 1984. "On the Effects of Sterilized Intervention: An Analysis of Weekly Data." Journal of Monetary Economics 14(2): 133-150.

Romer, Christina, and David Romer. 2002a. "A Rehabilitation of Monetary Policy in the 1950s." American Economic Association Papers and Proceedings 92(2): 121-127.

Romer, Christina, and David Romer. 2002b. "The Evolution of Economic Understanding and Postwar Stabilization Policy," In Rethinking Stabilization Policy, 11-78. Federal Reserve Bank of Kansas City.

Sachs, Jeffrey. 1985. "The Dollar and the Policy Mix, 1985." Brookings Papers on Economic Activity 16(1): 117-185.

Shin, Hyun. 2012. "Global Banking Glut and Loan Risk Premium.” IMF Economic Review 60(2): 155-192. 
Solomon, Robert. 1977. The International Monetary System 1945-1976: An Insider's View. New York: Harper \& Row.

Taylor, John. 1999. “A Historical Analysis of Monetary Policy Rules.” In Monetary Policy Rules, edited by John Taylor, 319-348. University of Chicago Press.

Triffin, Robert. 1960. Gold and the Dollar Crisis. New Haven: Yale University Press.

Wheeler, Graeme. 2013. "Manufacturing Decline Not Just a Dollar Story." Speech delivered to the New Zealand Manufacturers and Exporters Association, Auckland (20 February), http://www.rbnz.govt.nz/speeches/5150125.html .

White, William. 2009. “Should Monetary Policy 'Lean or Clean?'” Globalization and Monetary Policy Institute Working Paper 34. Federal Reserve Bank of Dallas (August).

Wigmore, Barrie. 1987. "Was the Bank Holiday of 1933 Caused by a Run on the Dollar?" Journal of Economic History 47(3): 739-755. 